\title{
1,3-OXAZOLIDIN-5-ONES DERIVED FROM PROLINE AS CHIRAL COMPONENTS IN THE SYNTHESIS OF PREDICTIVE ENANTIOSELECTIVE COUPLING REAGENTS
}

\author{
KATARZYNA KASPEROWICZ-FRANKOWSKA, BEATA KOLESIŃSKA, ANNA GZIK, \\ KONRAD JASTRZĄBEK and ZBIGNIEW J. KAMIŃSKI*
}

Institute of Organic Chemistry, Lodz University of Technology, Żeromskiego 116, 90-924 Łódź, Poland

\begin{abstract}
Oxazolidin-5-ones derived from both enantiomers of proline and trichloroacetaldehyde were prepared and applied as an amine component in the synthesis of chiral predictive triazine-based coupling reagents. The reagents were found to be useful in condensations yielding enantiomerically enriched products from racemic substrates.
\end{abstract}

Keywords: enantioselective condensation, triazine coupling reagent, peptide synthesis, chirality transfer to nitrogen, chiral nitrogen atom

Limited access to stereochemically homogeneous compounds is a crucial factor inhibiting the search for new pharmaceutically active compounds. Predictive chiral coupling reagents are a novel synthetic tool, enabling enantioselective acylation using racemic carboxylic components (1-3). The most important advantage of predictive enantioselective coupling reagents, particularly for the synthesis of complex molecules, is that configuration, enantiomeric enrichment and the efficiency of the coupling procedure are knowable on the basis of a single model experiment. This is possible due to the modular structure of enantiodifferentiating reagents. The reagents are composed of two fragments: achiral, substituted 1,3,5-triazine derivatives and chiral tertiary amine, which is prone to quaternization and the formation of $N$-triazinylamonium salts when treated with chloro-1,3,5-triazine. The chiral fragment is active throughout the activation step, determining enantioselectivity, but then departs once it has fulfilled its stereoselective function. Thus, all further reaction steps proceed in the presence of the achiral module only, which is the same as one in all well-known achiral triazine reagents (4).

It has been confirmed that the application of a predictive enantiodifferentiating coupling reagent for coupling racemic carboxylic components leads very efficiently to enantiomerically enriched acylated products. The most efficient stereodiscrimination has been observed for reagents prepared from alkaloids such as strychnine and brucine, bearing a stereogenic center on the nitrogen atom in the bridgehead position of the bicyclic system (1-3). In most cases, incorporation of the single enantiomer of the racemic amino acid substrate affords high yields of peptide chains (in the range of $85-95 \%$ ), with enantiomeric enrichment reaching up to $98-99 \%$. Unfortunately, chiral reagents obtained from alkaloids occur in only one enantiomeric form and are toxic, which limits the scope of their synthetic applications. In order to overcome these limitations, in this study we attempted to use as a chiral component amino acid derivatives available in both enantiomeric forms. We attempted to obtained 1,3-oxazolidin5-ones derived from L- and D-proline with a variety of aldehydes. These were then used for the synthesis of new chiral coupling reagents. The advantage of bicyclic 1,3-oxazolidin-5-ones prepared from proline is its configurational stability; an effect of the processes of chirality transfer and chirality selfregeneration postulated by Seebach (5).

\section{MATERIALS AND METHODS}

Synthesis of benzaldehyde dimethyl acetal (3a). Typical procedure (6)

To a mixture of benzaldehyde $(20 \mathrm{~mL}, 0.2$ mol) and 2,2-dimethoxypropane (49 mL, $0.4 \mathrm{~mol})$, a

\footnotetext{
* Corresponding author: e-mail: zbigniew.kaminski@p.lodz.pl
} 
catalytic amount of 4-toluenesulfonic acid (50 mg) was added. Acetone was distilled off using a short Vigreaux column. After collecting a stoichiometric amount of the acetone, the remaining clear liquid was diluted with dichloromethane $(50 \mathrm{~mL})$, cooled to $0^{\circ} \mathrm{C}$ and washed with a saturated aqueous solution of sodium bicarbonate. The organic phase was collected, dried with anhydrous potassium carbonate and distilled under reduced pressure. Fraction $\mathrm{bp}=$ $79^{\circ} \mathrm{C}, \mathrm{p}=11 \mathrm{~mm} \mathrm{Hg}$, was collected, yielding benzaldehyde dimethyl acetal (3a) (20.44 g, 67\%) lit. (7) $\mathrm{bp}=79^{\circ} \mathrm{C}, \mathrm{p}=11 \mathrm{~mm} \mathrm{Hg}$ as colorless liquid.

${ }^{1} \mathrm{H}-\mathrm{NMR}$ (pyridine $\left.\mathrm{D}_{5}\right): \delta=3.59(\mathrm{~s}, 6 \mathrm{H}$, $\left.\mathrm{OCH}_{3}\right) ; 5.79$ (s, 1H, -CH-); 7.45-7.72 (m, 5H, $\left.\mathrm{C}_{6} \mathrm{H}_{5}\right)$ [ppm].

Synthesis of 2,3-dimethoxybenzaldehyde dimethyl acetal (3b)

Synthesis was performed according to the typical procedure using 2,3-dimethoxybenzaldehyde (1.66 g, $10 \mathrm{mmol}$ ) and 2,2-dimethoxypropane (2.45 $\mathrm{mL}, 20 \mathrm{mmol}$ ), yielding after fractional distillation 2,3-dimethoxybenzaldehyde dimethylacetal (3b) $(0.44 \mathrm{~g}, 21 \%), \mathrm{bp}=149^{\circ} \mathrm{C} \mathrm{p}=19 \mathrm{~mm} \mathrm{Hg}$, as colorless liquid.

${ }^{1} \mathrm{H}-\mathrm{NMR}$ (toluene $\left.\mathrm{D}_{8}\right): \delta=3.21\left(\mathrm{~s}, 6 \mathrm{H}, \mathrm{CH}_{3} \mathrm{O}\right)$; $3.42\left(\mathrm{~s}, 3 \mathrm{H}, \mathrm{CH}_{3} \mathrm{O}\right) ; 3.80\left(\mathrm{~s}, 3 \mathrm{H}, \mathrm{CH}_{3} \mathrm{O}\right) ; 5.79(\mathrm{~s}, 1 \mathrm{H}$, -CH-); $6.60\left(\mathrm{~d}, 1 \mathrm{H}, J=8.2 \mathrm{~Hz} \mathrm{C}_{6} \mathrm{H}_{3}\right) ; 6.92(\mathrm{t}, 1 \mathrm{H}, J$ $\left.=7.9 \mathrm{~Hz} \mathrm{C}_{6} \mathrm{H}_{3}\right) ; 7.31\left(\mathrm{~d}, 1 \mathrm{H}, J=7.8 \mathrm{~Hz} \mathrm{C}_{6} \mathrm{H}_{3}\right)[\mathrm{ppm}]$.

\section{Synthesis of 3,4-dimethoxybenzaldehyde dimeth- yl acetal (3c)}

Synthesis was performed according to the typical procedure using 3,4-dimethoxybenzaldehyde (1.66 g, $10 \mathrm{mmol}$ ) and 2,2-dimethoxypropane (2.45 $\mathrm{mL}, 20 \mathrm{mmol})$, yielding after fractional distillation 3,4-dimethoxybenzaldehyde dimethylacetal (3c) (1.17 g, 55\%), bp $=124-128^{\circ} \mathrm{C}, \mathrm{p}=0.3 \mathrm{~mm} \mathrm{Hg}$, lit. (8) $\mathrm{bp}=115-125^{\circ} \mathrm{C}, \mathrm{p}=0.1 \mathrm{~mm} \mathrm{Hg}$ ) as a colorless oil.

${ }^{1} \mathrm{H}-\mathrm{NMR}$ (toluene $\left.\mathrm{D}_{8}\right): \delta=3.77\left(\mathrm{~s}, 6 \mathrm{H}, \mathrm{CH}_{3} \mathrm{O}\right)$; 4.19 (s, 6H, $\left.\mathrm{CH}_{3} \mathrm{O}\right) ; 5.93$ (s, 1H, - $\left.\mathrm{CH}-\right) ; 7.4$ (d, $1 \mathrm{H}$,

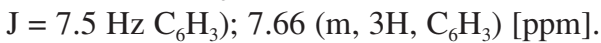

\section{Synthesis of 2-phenyl-1-aza-3-oxabicyxlo[3.3.0] octan-4-one (5a). Typical procedure}

A suspension of L-proline $(0.23 \mathrm{~g}, 2 \mathrm{mmol})$ in benzaldehyde dimethyl acetal $(\mathbf{3 a})(2 \mathrm{~mL})$ with a catalytic amount of $\mathrm{N}$-methylmorpholine 4-toluenesulphonate was heated under nitrogen to a gentle boil and methanol was distilled off using a Vigreaux column. The solvent was removed under reduced pressure and the residue was analyzed using a GCMS Perkin Elmer Clarus 580, mass detector Clarus SQ 8
S Column: ELITE $5 \mathrm{MS} 30 \mathrm{~m} / 0.25 \mathrm{~mm} / 0.5 \mu \mathrm{m}$ film, temp. program $50^{\circ} \mathrm{C}$ for $3 \mathrm{~min}, 5^{\circ} \mathrm{C} / \mathrm{min}$ to $200^{\circ} \mathrm{C}$, $20^{\circ} \mathrm{C} / \mathrm{min}$ to $320^{\circ} \mathrm{C}, 320^{\circ} \mathrm{C}$ for $3 \mathrm{~min} ; \mathrm{m} / \mathrm{z}$ from 33 to 350 .

Synthesis of (5S)-2-(trichloromethyl)-1-aza-3oxabicyclo[3.3.0] octan-4-one (L-5d) from L-proline. Typical procedure

A suspension of L-proline $(5.76 \mathrm{~g}, 50 \mathrm{mmol})$ and trichloroacetaldehyde hydrate $(12.49 \mathrm{~g}, 75$ $\mathrm{mmol})$ in $\mathrm{CHCl}_{3}(60 \mathrm{~mL})$ was heated to a gentle boil for $6 \mathrm{~h}$ and the water was removed by azeotropic distillation. The residue was cooled to room temperature and then washed with distilled water $(2 \times 30$ $\mathrm{mL})$. The combined aqueous phases were extracted with chloroform $(3 \times 10 \mathrm{~mL})$ and the organic extracts were then combined and dried with anhydrous $\mathrm{MgSO}_{4}$. The solvent was removed under a vacuum and the solid residue was recrystallised from ethanol affording (5S)-2-(trichloromethyl)-1aza-3-oxabicyclo[3.3.0]octan-4-one (L-5d) (7.97 g, yield $66 \%$ ), $\mathrm{mp}=102-108^{\circ} \mathrm{C}$, lit (9) $\mathrm{mp}=108$ $109^{\circ} \mathrm{C}$.

IR (film): $v=3112(\mathrm{CH}), 2978(\mathrm{CH}), 2899$ $(\mathrm{CH}), 1782(\mathrm{C}=\mathrm{O}), 1322(\mathrm{C}-\mathrm{N}), 1044(\mathrm{C}-\mathrm{O})\left[\mathrm{cm}^{-1}\right]$.

${ }^{1} \mathrm{H}$ NMR $\left(250 \mathrm{MHz}, \mathrm{CDCl}_{3}\right): \delta=1.71-2.44$ (m, 4H, - $\left.\mathrm{CH}_{2}-\mathrm{CH}_{2}-\mathrm{CH}-\right)$; 3.13-3.39 (m, $\left.1 \mathrm{H}, \mathrm{CH}_{2}-\mathrm{N}\right)$; 3.40- 3.68 (m, 1H, $\left.\mathrm{CH}_{2}-\mathrm{N}-\right)$; 4.11-4.36 (m, 1H, -CH$\mathrm{C}(\mathrm{O})-) ; 5.22$ (s, $1 \mathrm{H},-\mathrm{CH}-\mathrm{CCl}_{3}$ ) [ppm].

Synthesis of (5R)-2-(trichloromethyl)-1-aza-3oxabicyxlo[3.3.0]octan-4-one (D-5d) from D-proline

Synthesis was performed using D-proline (11.5 $\mathrm{g}, 100 \mathrm{mmol})$ and trichloroacetaldehyde hydrate (24.81 g, $150 \mathrm{mmol})$ in $\mathrm{CHCl}_{3}(80 \mathrm{~mL})$. (R)-2(trichloromethyl)-1-aza-3-oxabicyclo[3.3.0]octan4-one (D-5e) $\left(6.39 \mathrm{~g}\right.$, yield 55\%), $\mathrm{mp}=105-107^{\circ} \mathrm{C}$, lit. (for L-enantiomer) (9) $\mathrm{mp}=108-109^{\circ} \mathrm{C}$ was obtained. Spectroscopic data were gathered identical to those collected for $\mathrm{S}$ enantiomer.

Condensation of 4-methoxybenzoic acid with 4toluidine mediated by CDMT and (5S)-2(trichloromethyl)-1-aza-3-oxabicyclo[3.3.0]octan4-one (L-5d)

(5S)-2-(trichloromethyl)-1-aza-3-oxabicyclo[3.3.0]octan-4-one (L-5d) (0.061 g, $0.5 \mathrm{mmol})$ and 2-chloro-4,6-dimethoxy-1,3,5-triazine $(0.044 \mathrm{~g}$, $0.5 \mathrm{mmol})$ were dissolved in acetonitrile $(2 \mathrm{~mL})$ and stirred at room temperature for $24 \mathrm{~h}$. 4-Methoxybenzoic acid $(0.038 \mathrm{~g}, 0.25 \mathrm{mmol})$ was added and stirring was continued for 3 days until all the CDMT was consumed. 4-toluidine $(0.027 \mathrm{~g}, 0.25 \mathrm{mmol})$ 
was added and the clear solution was left at room temperature for an additional $12 \mathrm{~h}$. The solvent was removed under reduced pressure and the residue was dissolved in dichloromethane $(10 \mathrm{~mL})$. It was then washed thoroughly with water $(5 \mathrm{~mL}), 1 \mathrm{M}$ aq. $\mathrm{HCl}$ $(5 \mathrm{~mL})$, water $(5 \mathrm{~mL}), 1 \mathrm{M}$ aq. $\mathrm{NaHCO}_{3}(5 \mathrm{~mL})$ and again with water $(5 \mathrm{~mL})$. The solvent was evaporated, affording 4-methoxy-4'-methylbenzanilide $(0.024 \mathrm{~g}$, yield $40 \%)$ as white solid, $\mathrm{mp}=140^{\circ} \mathrm{C}$, lit. $\mathrm{mp}=150^{\circ} \mathrm{C}(10)$.

IR (film): $v=3339,3080,3006,2962,2917$, 2840, 1901, 1746, 1707, 1650, 1595, 1578, 1514, 1499, 1464, 1444; 1402, 1378, 1321, 1307, 1295, 1237, 1178, 1122, 1101, 1030, 967, 936, 898, 837, $811,792,760,653,639,626,610,541,504,430$, $399\left[\mathrm{~cm}^{-1}\right]$.

${ }^{1} \mathrm{H}-\mathrm{NMR}\left(250 \mathrm{MHz}, \mathrm{CDCl}_{3}\right): \delta=2.34(\mathrm{~s}, 3 \mathrm{H}$, $\mathrm{CH}_{3}-$ ); 3.87 (s, $\left.3 \mathrm{H},-\mathrm{OCH}_{3}\right) ; 7.1$ (dd, $4 \mathrm{H},-\mathrm{C}_{6} \mathrm{H}_{4}, J_{1}=$ $\left.8.23 \mathrm{~Hz}, J_{2}=48.96 \mathrm{~Hz}\right) ; 7.65\left(\mathrm{dd}, 4 \mathrm{H},-\mathrm{C}_{6} \mathrm{H}_{4}, J_{1}=\right.$ $8.93 \mathrm{~Hz}, J_{2}=48.96 \mathrm{~Hz}$ ) [ppm].

Condensation of 4-methoxybenzoic acid with 4toluidine mediated by CDMT and (5R)-2-(trichloromethyl)-1-aza-3-oxabicyclo[3.3.0] octan-4one (D-5d)

Condensation was performed as described above, using (5S)-2-(trichloromethyl)-1-aza-3-oxabicyclo[3.3.0] octan-4-one (D-5d) (0.122 g, 0.5 $\mathrm{mmol})$, 2-chloro-4,6-dimethoxy-1,3,5-triazine (0.088 g, $0.5 \mathrm{mmol})$, acetonitril (3 mL), 4-methoxybenzoic acid (0.076 g, $0.5 \mathrm{mmol}), 90 \mu \mathrm{L}(0.5 \mathrm{mmol})$ DIPEA and 4-toluidine $(0.053 \mathrm{~g}, 0.5 \mathrm{mmol})$. After evaporation of the solvent, crude 4-methoxy-4'-methylbenzanilide $(0.037 \mathrm{~g}$, yield $31 \%)$ was obtained as a white solid $\mathrm{mp}=140^{\circ} \mathrm{C}$, lit. $(10) \mathrm{mp} .=150^{\circ} \mathrm{C}$.

IR(film): $v=3339,3080,3006,2962,2917$, 2840, 1901, 1746, 1707, 1650, 1595, 1578, 1514, 1499, 1464, 1444, 1402, 1378, 1321, 1307, 1295, 1237, 1178, 1122, 1101, 1030, 967, 936, 898, 837, $811,792,760,653,639,626,610,541,504,430$, $399\left[\mathrm{~cm}^{-1}\right]$.

${ }^{1} \mathrm{H}-\mathrm{NMR}\left(250 \mathrm{MHz}, \mathrm{CDCl}_{3}\right): \delta=2.34(\mathrm{~s}, 3 \mathrm{H}$, $\left.\mathrm{CH}_{3}-\right) ; 3.87$ (s, 3H, $\left.-\mathrm{OCH}_{3}\right) ; 7.10\left(\mathrm{dd}, 4 \mathrm{H},-\mathrm{C}_{6} \mathrm{H}_{4}, J_{1}\right.$ $\left.=8.23 \mathrm{~Hz}, J_{2}=48.96 \mathrm{~Hz}\right) ; 7.65\left(\mathrm{dd}, 4 \mathrm{H},-\mathrm{C}_{6} \mathrm{H}_{4}, J_{1}=\right.$ $8.93 \mathrm{~Hz}, J_{2}=48.96 \mathrm{~Hz}$ ) [ppm].

Synthesis of Z-Ala-Gly-OMe using (5S)-2-(trichloromethyl)-1-aza-3-oxabicyclo[3.3.0] octan-4one (L-5d) and CDMT

A solution of (5S)-2-(trichloromethyl)-1-aza3-oxabicyclo[3.3.0] octan-4-one (L-5d) (0.244 g, 1 mmol) and CDMT (0.175 g, $1 \mathrm{mmol})$ was stirred at $10^{\circ} \mathrm{C}$ for 24 h. rac-Z-AlaOH $(0.446 \mathrm{~g}, 2 \mathrm{mmol}$ and DIPEA $(180 \mu \mathrm{L}, 1 \mathrm{mmol})$ were added and stirring was continued at $10^{\circ} \mathrm{C}$ for $48 \mathrm{~h}$. $\mathrm{H}-\mathrm{GlyOMe} * \mathrm{HCl}$ (0.126 g, $1 \mathrm{mmol})$ and DIPEA $(180 \mu \mathrm{L}, 1 \mathrm{mmol})$ were added and the mixture was stirred for an additional $24 \mathrm{~h}$ at room temperature. The solvent was evaporated and the solid residue was dissolved in dichloromethane $(25 \mathrm{~mL})$. It was then washed successively with water $(25 \mathrm{~mL}), 1 \mathrm{M}$ aq. $\mathrm{NaHSO}_{4}(25$ $\mathrm{mL})$, water $(25 \mathrm{~mL}), 1 \mathrm{M}$ aq. $\mathrm{NaHCO}_{3}(25 \mathrm{~mL})$ and again with water $(25 \mathrm{~mL})$. The organic phase was dried with $\mathrm{MgSO}_{4}$ and filtered. The filtrate was evaporated to dryness, affording crude Z-Ala-GlyOMe $(0.255 \mathrm{~g}, 87 \%$ yield $)$. The solid residue was purified using column chromatography on silica gel. The product was eluted with hexane/ethyl acetate, affording Z-AlaGly-OMe (0.056 g, yield 19\%), mp $=93-95^{\circ} \mathrm{C},[\alpha]_{\mathrm{D}}^{20}=-12.3(\mathrm{c}=1 \mathrm{~g} / 100 \mathrm{~mL})$, lit. $(11)$ (for Z-L-Ala-Gly-OMe) $\mathrm{mp}=96-96.5^{\circ} \mathrm{C},[\alpha]_{\mathrm{D}}^{25}=-$ 27 (c = 1.0, MeOH).

IR (film/NaCl): $v=3321,3017,2966,2937$, 2903, 2274, 2143, 1984, 1815, 1759, 1695, 1666, 1586, 1536, 1480, 1448, 1410, 1374, 1362, 1320, 1247, 1191, 1168, 1127, 1072, 1054, 1017 [ $\left.\mathrm{cm}^{-1}\right]$. ${ }^{1} \mathrm{H}-\mathrm{NMR}\left(250 \mathrm{MHz}, \mathrm{CDCl}_{3}\right): \delta=1.41(\mathrm{~d}, 3 \mathrm{H}, \mathrm{J}=6.5$ $\mathrm{Hz}, \mathrm{CH}_{3}-\mathrm{CH}-$ ); 3.78 (s, 3H, $\mathrm{CH}_{3} \mathrm{O}-$ ); 4.11 (q, 2H, J = $7 \mathrm{~Hz}, \mathrm{CH}_{3}-\mathrm{CH}_{2}-\mathrm{O}-$ ); 4.39 (m, 1H, $\mathrm{CH}_{3}-\mathrm{CH}-$ ); 5.10 (s, 2H, - $\mathrm{CH}_{2} \mathrm{O}-$ ); 6.61 (broad s, $\left.1 \mathrm{H}, \mathrm{NH}\right) ; 7.40$ (s, $5 \mathrm{H}$, arom.) [ppm].

Synthesis of Z-AlaGlyOMe using (5R)-2-(trichloromethyl)-1-aza-3-oxabicyclo[3.3.0] octan-4-one (D-5d) and CDMT

Synthesis was performed as described above, using (5R)-2-(trichloromethyl)-1-aza-3-oxabicyclo[3.3.0]octan-4-one (D-5e) (0.244 g, $1 \mathrm{mmol})$, CDMT (0.175 g, $1 \mathrm{mmol})$, rac-Z-AlaOH (0.446 g, 2 mmol), DIPEA $(180 \mu \mathrm{L}, 1 \mathrm{mmol}) \mathrm{H}-\mathrm{GlyOMe} * \mathrm{HCl}$ $(0.126 \mathrm{~g}, 1 \mathrm{mmol})$ and DIPEA $(180 \mu \mathrm{L}, 1 \mathrm{mmol})$. Crude Z-AlaGlyOMe (0.223 g, 76\% yield) was afforded as a pale yellow oil. After column chromatography, Z-Ala-Gly-OMe was isolated $(0.039 \mathrm{~g}$; yield $13.25 \%$ ), $\mathrm{mp}=89-92^{\circ} \mathrm{C}$; lit. (12) (for Z-D-AlaGly-OMe $),[\alpha]=+16(\mathrm{c}=0.35 \mathrm{~g} / 100 \mathrm{~mL}) \mathrm{mp}=94-$ $95^{\circ} \mathrm{C}$, lit. (13) (for Z-D-Ala-Gly-OMe) $[\alpha]_{\mathrm{D}}^{20}=+26$ (c=1 g/100 mL MeOH). Spectroscopic data were gathered identical to those collected for the product described in 4.2 .

\section{RESULTS AND DISCUSSION}

The characteristic feature of all the alkaloids which were found to be especially efficient as chiral components in predictive enantioselective coupling reagents was the presence of aromatic rings in proximity to the bridgehead chiral nitrogen atom. 
Therefore, in preliminary experiments it was attempted to transform proline into the bicyclic system, through treatment with benzaldehyde or benzaldehyde acetal. Intensive diastereoselection was expected to occur during the process of chirality transfer.

Unexpectedly, contrary to successful experiments with trimethylacetaldehyde described by Seebach (5) or with trichloroacetaldehyde reported by Germanas (14), we were unable to isolate the expected product 5a with a phenyl group in position 2 of the 1,3-oxazolidinone ring.

GCMS analysis of the reaction mixture showed the presence of the main product at $\mathrm{R}_{\mathrm{t}}=38.85 \mathrm{sec}$ (see Figure 1), for which the fragmentation pattern is presented in Figure 2.

The fragmentation pattern and molecular ion $[\mathrm{M}+1]=247.1798$ depicted in Figure 2 strongly suggest that the main product of the reaction is the expected 1,3-oxazolidinone 5a.

Identification of oxazolidinone as the main reaction product supported the conclusion that $\mathbf{5 a}$ is extremely unstable and readily decomposed during the isolation procedure. To increase the stability of 1,3-oxazolidinone, dimethyl acetals $\mathbf{5 b}$-c substituted with electron-donating groups $\mathrm{G}$ were prepared and used for cyclization with proline. Unfortunately, all attempts to improve the stability of 5a-c by modulating the electron density in the aromatic ring were unsuccessful. GCMS analysis for all $\mathbf{5 b}$-c confirmed the presence of the molecular ion and showed the expected fragmentation pattern, analogous to that presented in Figure 2 for 5a. Therefore, attention was focused on 1,3-oxazolidinone $\mathbf{5} \mathbf{d}$ formed from trichloroacetaldehyde hydrate and proline, as described by Germanas (14).

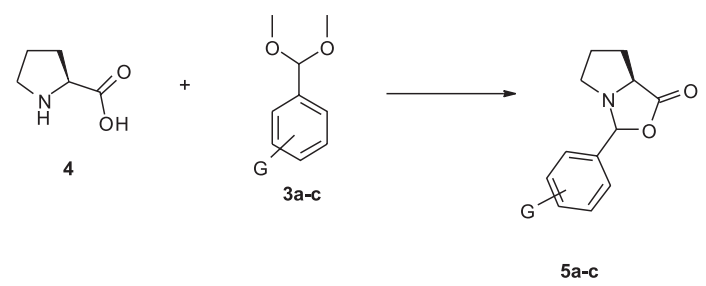

Scheme 1. Synthesis of oxazolidinone 5a-c from proline and benzaldehyde dimethyl acetal

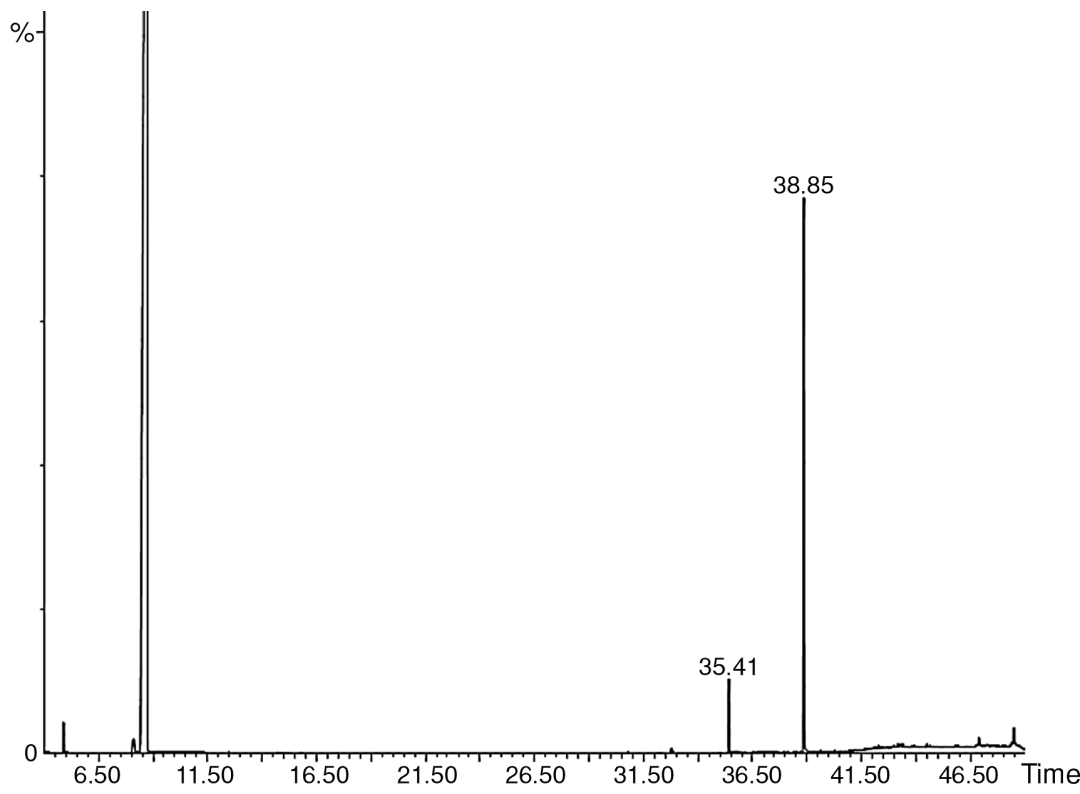

Figure 1. GC analysis of a reacting mixture of 4 and 3a. Column: ELITE $5 \mathrm{MS} 30 \mathrm{~m} / 0.25 \mathrm{~mm} / 0.5 \mu \mathrm{m}$ film, helium as carrier gas $30 \mathrm{~mL} / \mathrm{s}$; temp. program $50^{\circ} \mathrm{C}$ for $3 \mathrm{~min}, 5^{\circ} \mathrm{C} / \mathrm{min}$ to $200^{\circ} \mathrm{C}, 20^{\circ} \mathrm{C} / \mathrm{min}$ to $320^{\circ} \mathrm{C}, 320^{\circ} \mathrm{C}$ for $3 \mathrm{~min}$ 


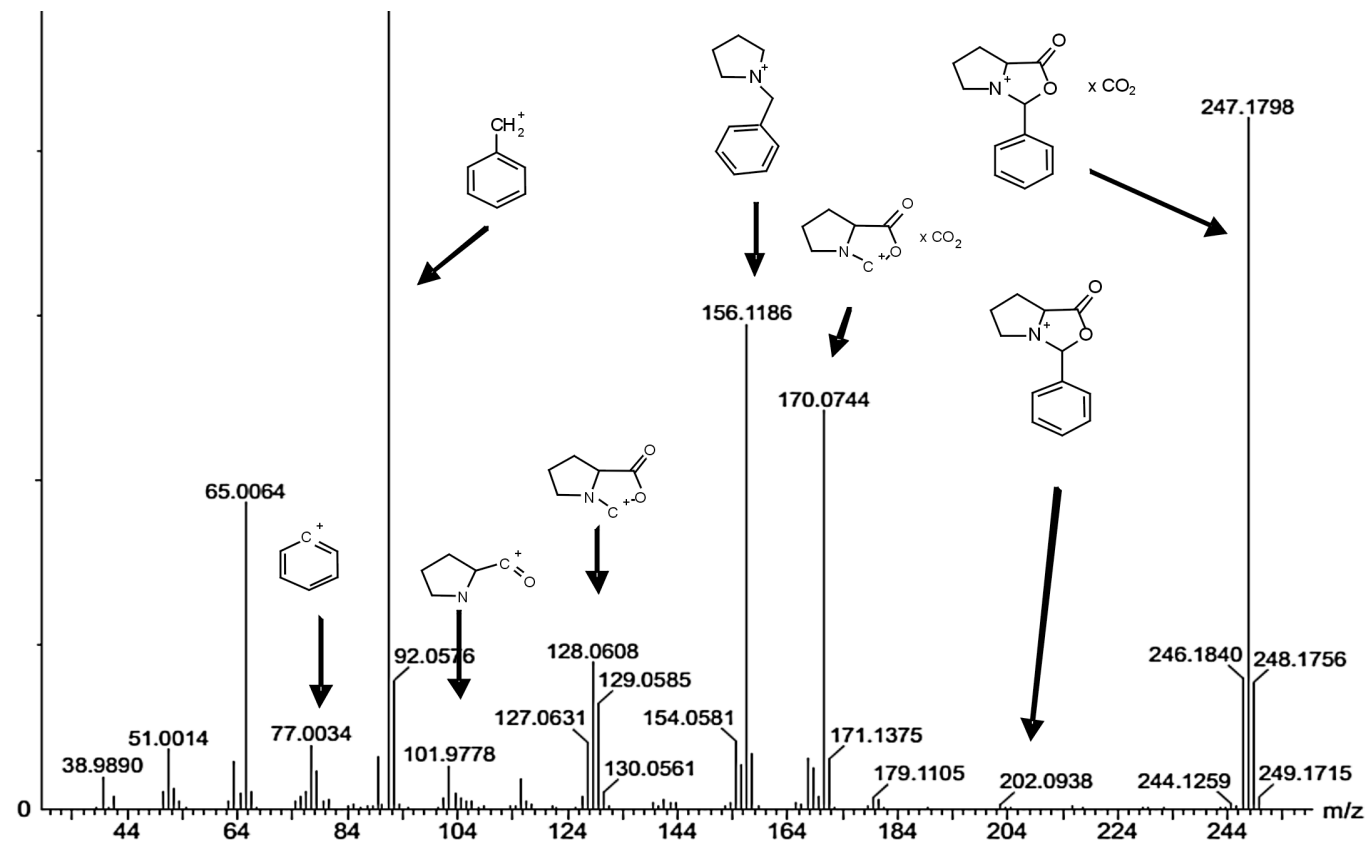

Figure 2. Fragmentation pattern for the main product formed in the reaction of proline (4) with benzaldehyde dimethyl acetal $\mathbf{3 a}$ (signal at $\mathrm{R}_{\mathrm{t}}=38.85$ min on chromatogram presented in Fig. 1)

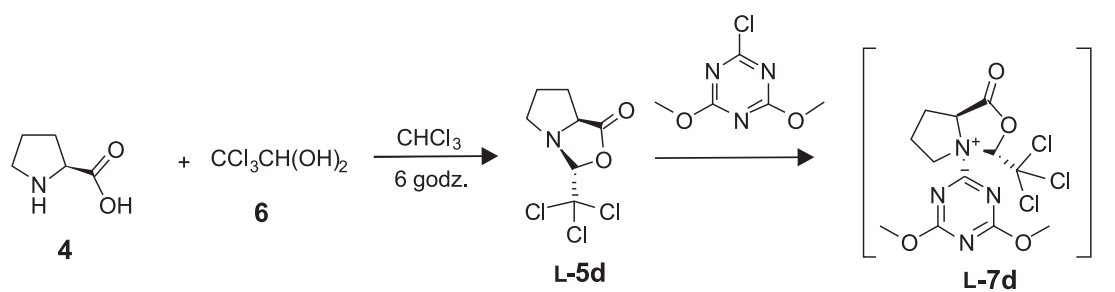

Scheme 2. Synthesis of N-triazinylammonium salt L-7d via (5S)-2-(trichloromethyl)-1-aza-3-oxabicyclo[3.3.0]octan-4-one (L-5d) and 2chloro-4,6-dimethoxy-1,3,5-triazine<smiles>CC(NC(=O)OCc1ccccc1)C(=O)O</smiles><smiles>[Te][Te]</smiles><smiles>COc1nc(OC)nc(OC(=O)C(C)NC(=O)OCc2ccccc2)n1</smiles><smiles>COc1nc(OC)nc(OC(=O)CNC(=O)OCc2ccccc2)n1</smiles><smiles>COC(=O)CNC(=O)C(C)NC(=O)OCc1ccccc1</smiles><smiles>COC(=O)CNC(=O)CNC(=O)OCc1ccccc1</smiles>

Scheme 3. Enantioselective activation of rac-Z-Ala-OH using coupling reagent L-7d or D-7d generated in situ 
Cyclization via azeotropic dehydration (15) of the mixture of proline and trichloroacetaldehyde hydrate gave the expected product L-5d with a $66 \%$ yield. The enantiomer D-5d was prepared under the same conditions, from D proline, with a $55 \%$ yield. In both preparations, the presence of a sharp singlet of $\mathrm{C} 2$ proton at $5.20 \mathrm{ppm}$ in the NMR spectrum confirmed the configurational stability of $\mathbf{5 d}$.

Preliminary studies on the application of $\mathbf{5 d}$ in condensations mediated by triazine-coupling reagents were performed. The model reaction was coupling of 4-methoxybenzoic acid with 4-toluidine. Formation of $N$-triazinylammonium salts $\mathbf{L}$ 7d and D-7d in reactions of $\mathbf{L - 5} \mathbf{d}$ or $\mathbf{D - 5} \mathbf{d}$ with CDMT was found to proceed slowly. Nevertheless, both enantiomers of $\mathbf{5 d}$ activated 4-methoxybenzoic acid within 3 days and gave the expected substituted benzamide after $24 \mathrm{~h}$ of acylation of $p$-toluidine. Thus, even if the prolonged preactivation of CDMT and the formation of 7 in the presence of relatively nucleophilic chloride anione is tiresome, it is not thought to deteriorate the coupling procedure, since the quaternary ammonium group in the bridgehead position is substantially less prone to dealkylation (16). The crucial conditions for successful enantioselective coupling with $\mathbf{5 d}$ were the efficient transfer of chirality onto the nitrogen atom and the suppression of anhydride formation (17).

Enantioselective coupling with a preactivation stage leading to $\mathbf{7 d}$, followed by $48 \mathrm{~h}$ activation of rac-Z-Ala-OH, gave crude enantiomerically enriched L-Z-Ala-Gly-OMe using (5S)-2(trichloromethyl)-1-aza-3-oxabicyclo[3.3.0]octan4-one (L-5d) with $87 \%$ yield. The opposite enantiomere, D-Z-Ala-Gly-OMe, was isolated with a $76 \%$ yield as the crude product of condensation involving (5R)-2-(trichloromethyl)-1-aza-3-oxabicyclo[3.3.0]octan-4-one (D-5d). In order to remove contamination caused by chiral side-products, both peptides were thoroughly purified on a silica gel column before their enantiomeric composition was determined via photopolarimetric measurements. Measurements showed a preference for the activation of the $\mathrm{L}$ enatiomeric form of Z-Ala-OH (L/D ratio $=76 / 24)$ when $(5 S)$-2-(trichloromethyl)-1-aza3-oxabicyclo[3.3.0] octan-4-one (L-5d) was used as the chiral component in the predictive coupling reagent L-7d. In condensation involving (5R)-2(trichloromethyl)-1-aza-3-oxabicyclo[3.3.0]octan4-one (D-5d) as the chiral component of D-7d, activation of the $\mathrm{D}$ enatiomeric form of $\mathrm{Z}-\mathrm{Ala}-\mathrm{OH}$ was preferred $(\mathrm{L} / \mathrm{D}$ ratio $=76 / 24)$.

\section{CONCLUSION}

The synthetic versatility of 1,3-oxazolidinone described by Seebach (5) and Germanas (14) was further confirmed by application of 2-(trichloromethyl)-1-aza-3-oxabicyclo[3.3.0] octan-4-one (5d), which is accessible in both enantiomeric forms, as the chiral module in predictable enantioselective coupling reagents. As expected, giving access to both enantiomeric forms of the reagent formed in situ made it possible to incorporate the expected enantiomeric amino acid residue into the peptide chain from a racemic mixture of substrates. Given that only two equivalents of racemic substrates were used for one equivalent of the chiral coupling reagent, enantiomeric enrichment in this process of kinetic resolution can be considered highly efficient. Unfortunately, our attempts to prepare the more reactive and less sterically hindered 1,3-oxazolidinone have, as yet, been unsuccessful.

\section{Acknowledgment}

This study was supported by the Ministry of Science and High Education under the Research Project from National Science Center: project number: 2012/07/N/ST5/01883

\section{REFERENCES}

1. Kolesińska B., Kamiński Z. J.: Org. Lett. 11, 765 (2009).

2. Kolesińska B., Kasperowicz K., Sochacki M., Mazur A., Jankowski S., Kamiński Z. J.: Tetrahedron Lett. 51, 20 (2010).

3. Kolesińska B., Kasperowicz-Frankowska K., Frączyk J., Kamiński Z. J.: Helv. Chim. Acta 95, 2084 (2012).

4. Kamiński Z. J.: Biopolymers 55, 140 (2000).

5. Seebach D., Beck A.K., Badine D.M., Limbach M., Eschenmoser A. et al.: Helv. Chim. Acta 90, 425 (2007).

6. Roeschlaub C.A., Sammes P.G.: J. Chem. Soc., Perkin Trans. 1, 2243 (2000).

7. Pornet J., Randrianoelina B., Miginiac L.: J. Organometall. Chem. 174, 15 (1979).

8. Perkin W.H., Robinson R., Stoyle F.W.: J. Chem. 125, 2355 (1924).

9. Aaron G.L., Artman G.D., Brummond K.M., Davis M.M., Rafferty R.J., Williams R.M.: Org. Synth. 86, 262 (2009).

10. Avenoza A., Pereprine J.: Tetrahedron 58, 10107 (2002). 
11. Kawasaki K., Tsuji T., Maeda M., Matsumoto T., Hirase K.: Chem. Pharm. Bull. Jpn. 35, 1044 (1987).

12. Hammadi A.; Nuzillard J.M.; Poulin J.C.; Kagan H.B.: Tetrahedron: Asymmetry 3, 1247 (1992).

13. Grzonka Z., Palacz Z., Baran L., Przegaliński E., Kupryszewski G.: Pol. J. Chem. 55, 1025 (1981).
14. Wang H., Germanas J.P.: Synlett 1, 33 (1999).

15. Harris P.W.R., Brimble M.A., Muir V.J., Lai M.Y.H., Trotter N.S., Callis D.J.: Tetrahedron 61, 10018 (2005).

16. Kolesińska B., Kamiński Z.J.: Tetrahedron 65, 3573 (2009).

17. Kamiński Z.J., Kolesińska B., Marcinkowska M.: Synth. Commun. 34, 3349 (2004).

Received: 03. 10. 2017 